Journal of Social Sciences (COES\&RJ-JSS)

ISSN (E): 2305-9249 ISSN (P): 2305-9494

Publisher: Centre of Excellence for Scientific \& Research Journalism, COES\&RJ LLC

Online Publication Date: $1^{\text {st }}$ April 2018

Online Issue: Volume 7, Number 2, April 2018

https://doi.org/10.25255/jss.2018.7.2.61.73

\title{
How to Bridge the Audit Expectation Gap?
}

Hasan Mansur - PhD Candidate, Szent Istvan University, Doctoral school of Management and Business Administration Sciences, Pater Karolyutca, Hungary. https://orcid.org/0000-0003-0806-4589

Anita Tangl - Associate Professor, Szent Istvan University, Faculty of Economics and Social Sciences, Godollo, Hungary. https://orcid.org/0000-0003-0418-5439

\section{Abstract}

Purpose: This paper aimed to highlight the possibilities to bridge the audit expectation gap between external auditors and stakeholders.

Design/Type of Research: This paper is a review study based on the analysis of previous studies, reports and publications that are related to audit expectation gap, external audit profession and public perceptions towards the external auditors.

Limitations/Implications: The paper focused on audit expectation gap in the field of accounting and auditing.

Conclusion

Conclusions are summarized as the following:

- The audit expectation gap can be bridged through much more experiences, training, effort for auditors, and much more educating for financial statements' users about the role and nature of audit profession.

- Audit expectation gap could be bridged between external auditors and stakeholders, but couldn't be eliminated completely.

- Better communication between the auditors and the society may help reduce the gap.

\section{Recommendations}

There are some recommendations that could narrow the audit gap such as increase the awareness of public about the auditors' responsibilities and duties, and increase the practitioners' (external auditors) skills and abilities through education and training; increase the quality of audit standards.

Keywords:

Audit, Expectation Gap, Bridge the Gap

\section{Citation:}

Mansur, Hasan; Tangl; Anita (2018); How to Bridge the Audit Expectation Gap?; Journal of Social Sciences (COES\&RJ-JSS), Vol.7, No.2, pp:61-73;

https://doi.org/10.25255/jss.2018.7.2.61.73. 


\section{Introduction}

After increasing auditor's responsibility in recent years, which followed the lawsuit against external auditors, a lot of well-known audit firms and offices have taken a sharp criticism because some companies failed and collapsed later on such as Enron (Healy and Palepu, 2003). Enron was classified the most pioneering large company in America in Fortune magazine's survey of Most Well-regarded Companies. Yet within a year, Enron's image was in tatters and its stock price had plummeted nearly to zero (Healy and Palepu, 2003). Followed Enron, WorldCom which was the second largest communication firm in united states of America (Handley-Schashler and Li, 2005) and then collapse of Parmalat Co. for food in Italy (Benedetto and Castri, 2005). All of these events leaded to expectation gap between stakeholders and external Auditors.

The collapse of giant energy Enron, and collusion of Arthur Andersen for Audit which was considered one of the big Five audit companies at that time with Enron's officers, leaded to condemnation Arthur Andersen as it was the main reason of Enron's collapse, and the inquest demonstrated that the responsibility of Arthur Andersen lies in two sides, the first one that Arthur Andersen participated in concealing Enron's losses by establishing unreal companies and proclaimed that Enron shares and gets (unreal) profits. The second one that Arthur Andersen hid a lot of documents and papers during the investigation process (Handley-Schashler and Li, 2005). The expectation gap in auditing is critical to the auditing profession because the greater the unfulfilled perceptions from the public, the lower is the credibility, earning potential and prestige associated with the work of auditors (UKEssays, 2015).

The failures of living up to societal perceptions have implicated the notion of "audit expectation gap" (UKEssays, 2015). The "expectations gap" is the difference between what users of financial statements, the general public beliefs an audit to be and what the audit profession claim is expected of them in implementing an audit (Ojo, 2006). According to American Institute of Certified Public Accountant (AICPA) publications as cited in (Lexicon, 2017) the audit expectation gap is "the difference between what the public and financial statement users believe auditors are responsible for and what auditors themselves believe their responsibilities are". Whereas, Oxford (2010) defines audit expectation gap as The gap between the role of an auditor, as perceived by the auditor, and the expectations of the users of financial statements. It may be subdivided into a gap in communications and a gap in performance. Porter and Gowthorpe (2004) defined audit expectation gap "The gap between society's expectations of auditors; and auditors' performance as perceived by society".

If financial statements' users and the public were perceived that the auditor's role takes the detection and prevention of fraud, especially in relation to material items, the fraud and error detection role of an audit could be relatively objective. However, the Auditing Practices Board cannot guarantee full objectivity since materiality and material significance are subjective concepts, which require further clarification. (UKEssays, 2015). Therefore, financial scandals haven't been stopped on Enron and WorldCom, but a lot of scandals happened after that time such as a Madoff scandal, which leaded to incur losses around 1.5 Billion sterling pounds to one of the most financial institution all over the world: Hong Kong Shangahai banking Corporation HSBC (Obeidat et al., 2017; Masa'deh 
et al., 2015; Obeidat et al., 2013; Hmoud and Mansour, 2012; Zarrabi and Lunndberg, 2011).

In the light of these events, this paper will highlight on the audit expectation gap and, and how to bridge the gap between external auditors and public interests.

\section{Problem statement and contribution}

After increasing the criticism towards the profession of external audit, especially after Enron scandal, Worldcom, and then the financial collapse of several well-known firms in USA and Europe, many researchers starting to concern more about the opinions of different stakeholders towards the profession of external audit. This paper will make a new contribution about perceptions of stakeholders towards external auditors, through answering the research question: How to bridge the audit expectation gap between stakeholders and external auditors?

\section{Paper objective}

This paper aims to reach to the major enablers that might help in narrowing the gap between the perceptions of stakeholders and other financial statements' users towards external auditors.

\section{Methodology}

This paper is a review study based on previous literature studies, take into account the audit profession, audit expectation gap and the perceptions of public (society) and financial statements' users towards the external auditors and the profession of audit.

\section{Conceptual framework}

The communications gap is caused by public expectations being unreasonable; for example, users of accounts may expect all fraud to have been discovered by a statutory audit, whereas the auditor is only expected to plan the audit to prevent and detect fraud. Moreover, the communications gap could be closed by ensuring that the users of accounts understand what an audit is and what its limitations are. The performance gap occurs when public expectations are reasonable but the auditor's performance does not fulfill them, i.e. there is a shortfall in the auditor's performance (Oxford, 2010).

There are many users of the financial statements produced by an organization. The following list identifies the more common users of financial statements, and the reasons why they need this information (Accounting tools, 2014):

- Company management. The management team needs to understand the profitability, liquidity, and cash flows of the organization every month, so that it can make operational and financing decisions about the business.

- Competitors. Entities competing against a business will attempt to gain access to its financial statements, in order to evaluate its financial condition. The knowledge they gain could alter their competitive strategies.

- Customers. When a customer is considering which supplier to select for a major contract, it wants to review their financial statements first, in order to judge the financial ability of a supplier to remain in business long enough to provide the goods or services mandated in the contract. 
- Employees. A company may elect to provide its financial statements to employees, along with a detailed explanation of what the documents contain. This can be used to increase the level of employee involvement in and understanding of the business.

- Governments. A government in whose jurisdiction a company is located will request financial statements in order to determine whether the business paid the appropriate amount of taxes.

- Investment analysts. Outside analysts want to see financial statements in order to decide whether they should recommend the company's securities to their clients.

- Investors. Investors will likely require financial statements to be provided, since they are the owners of the business, and want to understand the performance of their investment.

- Lenders. An entity loaning money to an organization will require financial statements in order to estimate the ability of the borrower to pay back all loaned funds and related interest charges.

- Rating agencies. A rating agency will need to review the financial statements in order to give a credit rating to the company as a whole or to its securities.

- Suppliers. Suppliers will require financial statements in order to decide whether it is safe to extend credit to a company.

- Unions. A union needs the financial statements in order to evaluate the ability of a business to pay compensation and benefits to the union members that it represents.

Wedgandt, Kimmel, and Kieso (2015, pp. 5-6) demonstrates in Figure 1 the users of financial statements:

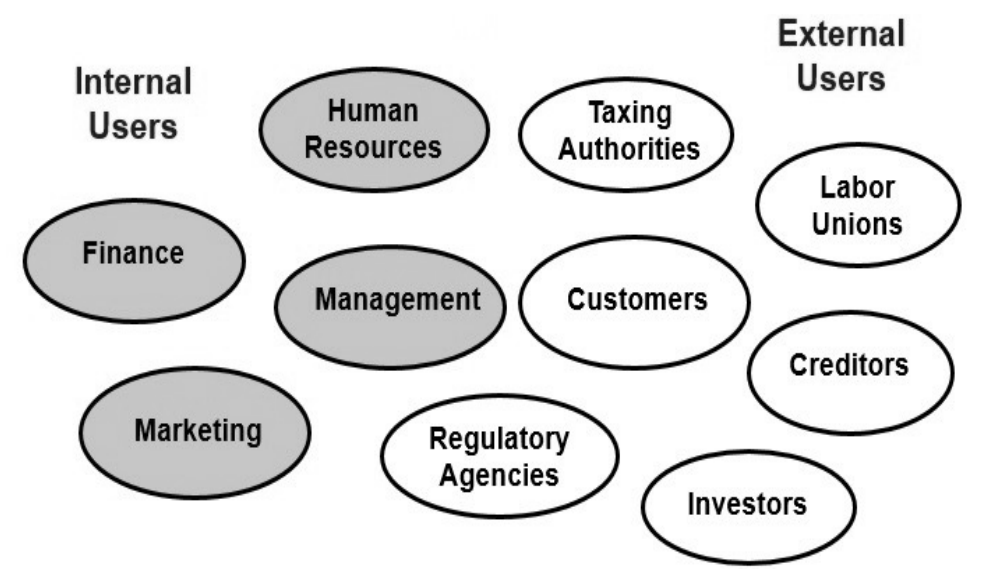

Figure 1: Internal and external users of financial statements

(Wedgandt et al., 2015, pp. 5-6).

In short, there are many possible users of financial statements, all having different reasons for wanting access to this information.

International Federation of Accountants IFAC (2012) defines the public interest as "The net benefits derived for, and procedural rigor employed on behalf of, all society in relation to any action, decision or policy. This definition can be readily applied to the accountancy profession and its responsibilities to the public. One can reasonably assert 
that some groups of the public, e.g., investors, employees, or other stakeholders may, due to their proximity to a particular institution, be more impacted by the work of accountants than others. However, the implications of the work of the accountancy profession the level of public confidence can affect the public on a much wider scale".

Moreover, (IFAC, 2012) considers that the "public" includes the widest possible scope of society: for example, individuals and groups sharing a marketplace for goods and services (including those provided by government), as well as those seeking sustainable living standards and environmental quality, for themselves and future generations. This includes:

- Investors, shareholders, and business owners of public and private institutions, This encompasses all parties whose resources and well-being depend upon the performance of such institutions. These parties rely upon sound financial information to make decisions about the allocation of their resources. This not only includes investors, but also employees and those who have pensions and other vested interests tied to the performance of such institutions.

- Consumers and suppliers - This encompasses all parties who are affected by the costs, quality, and availability of goods and services. Consumers and suppliers ultimately bear the impact of financial decision makers (and those who advise them). The quality of financial information and decision making impacts the efficiency of resource management, which in turn impacts goods and services produced.

- Taxpayers, electorates, and citizens - This encompasses all parties who are impacted by the work of public sector accounting professionals, who facilitate financial information, make financial decisions, and advise policymakers and elected officials. These include immediate short-term impacts, as well as medium and longer-term considerations and matters of sustainability. The efficient management of public resources (e.g. tax revenues, public properties, governmental organizations, infrastructure, and other resources) affects their costs, quality, and availability and, through these, society as a whole.

Although the impact of the work of the accountancy profession differs among these groups, there is a fundamental obligation for the profession to act in the public interest regardless of its proximity to these different groups.

Audit expectation gapcontains two types (Porter and Gowthorpe, 2004):

1. The reasonableness gap: which is the gap between what public expects of external auditors and what external auditors can reasonably be expected to accomplish.

2. The performance gap: The gap between what public can reasonably expect of external auditors and what it perceives they deliver.

This gap subdivided into:

a. The deficient standards gap: This gap appearsbetween the responsibilities public reasonably expects external auditors to accomplish and auditors' actual responsibilities as defined by regulations and professional promulgations;

b. The deficient performance gap: This gap appears betweenthe expected standard of performance of external auditors accomplishing these responsibilities and auditors' actual performance of these duties. 
Porter and Gowthorpe (2004) demonstrated the audit expectation-performance gap in figure 2:

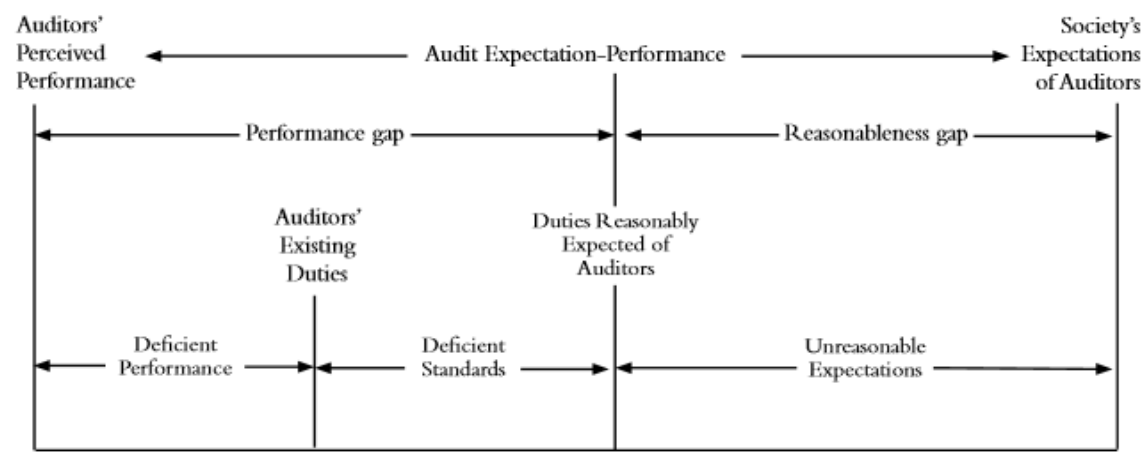

Figure 2: Audit expectation performance gap (Porter \& Gowthorpe, 2004)

\section{Literature review}

Several studies werediscussed from different contexts and cultures, highlightedon audit expectation gap, and how perceptions were similar or dissimilar from certain point or side. This paper will review and discuss these different studies, and highlight on the main reasons that might make differences between auditors and public expectation, in order to come out with finding and recommendation that might help in bridging the gap.

According to Sylph (2009), professional accountants who audit financial statements are waiting stream of changes. These changes related with:

- the regulatory environment for financial reporting and auditing;

- new standards on ethics, financial reporting, auditing and assurance;

- Being responsive to a variety of stakeholder needs and wants for more and different types of reporting and assurance.

These challenges are found in an environment where financial reporting is infinitely more complex than before and accountability arrangements are increasingly being made explicit in laws and regulations relating to corporate governance (Sylph, 2009).

Increased demands are also being made on directors on boards of corporate entities, who must be able to read and understand financial statements that they assume direct responsibility for. Chief financial officers also bear increased responsibility for preparation of financial information that recognizes the interests of public investors and other key stakeholders (Sylph, 2009).

Pourheydari and Abousaiedi (2011) investigated the audit expectation gap in Iran between the interested users and external auditors, and they used a survey to identify the expectation gap. They found that there is an expectation gap in certain areas of 
auditors' responsibilities for fraud detection, the soundness of internal controls and preparation of financial statements, whereas there were no differences between the two parties regarding to the utility and reliability of financial statements. The main implications to reduce the expectationgaps achieved through improvement in auditoruser communication in the audit reports as well as educating users on the nature and functions of audits.

Dixon, Woodhead, and Sohliman (2006) found an evidence of a wide audit expectation gap in Egypt in the areas of auditor responsibilities for fraud prevention, maintenance of accounting records, and auditor judgment in the selection of audit procedures. To a lesser extent, an expectation gap was found concerning the reliability of audit and audited financial statements, and the usefulness of audit; they implicated that In order to reduce the expectation gap and improve decisionmaking by financial statement users, the results of this study support the adoption of the long-form audit report, augmentation of the auditing framework, strengthening of the auditor's integrity, and finally educating users on the nature and functions of audit.Munir Sidani (2007) foundA significant "reasonableness gap" was uncovered in lebanon. There is a gap between the auditors' understanding of their profession compared with the perceptions of others. There is a significant difference in perceptions of the role of the auditor in respect of fraud detection; implicated that Much more concerted effort needs to be exercised from professional syndicates and other relevant stakeholders in developing the image of the profession and addressing the varying perceptions and attitudes towards it.

Haniffa and Hudaib (2007) offer an insight into the types of 'audit expectations gap' that exist within a cultural context. Specifically, it investigates if the business and social environment affect the perceptions of audit performance of users and auditors, and indicate that the inclusion of Islamic principles in auditing standards and the code of ethics would help reduce the expectations gap that exists in Saudi Arabia. Masoud (2017). T. H. Lee, Gloeck, and Palaniappan (2007) aimed to examines whether an expectation gap exists in Malaysia among the auditors, auditees and audit beneficiaries in relation to the auditors' duties, analyzed the nature of the gap. The results proved the existence of an audit expectation gap in Malaysia, and showed that the auditees and audit beneficiaries placed much higher expectations on the auditors' duties when compared with what auditors have perceived their duties to be. The analysis of the expectation gap indicated the existence of unreasonable expectations of the part of users; deficient standards of auditing in Malaysia; and deficient performance of auditors. Salehi and Rostami (2009) focused on the concepts and evidences of audit expectation gap, and reviewed a lot of studies from different cultures.Revealed that there is a consensus among the researchers that the gap arises due to over-expectations of users regarding the functions of an auditor and lack of knowledge about auditors' role and responsibilities have made the users to expect high. The literature also reveals that educating the public about the objects of an audit, auditors' role and responsibilities will help to narrow the audit expectation gap. Okafor and Otalor (2013) sought to ascertain the role of the auditing profession in narrowing the audit expectation gap, selfadministered questionnaires were used in the study. The data generated from the responses of the subjects were analyzed using descriptive and statistical analysis. The 
result showed that the public is ignorant of the duties of the auditor and this lack of knowledge is responsible for unreasonable expectations of the public from auditors.

Rehana (2010) carried out a research to investigate whether there is evidence that the provision of auditing subject as part of business degree programs contributes to narrowing that part of the audit expectation gap which results from a misunderstanding of audit regulations. Teo and Cobbin (2005) took the contemporary audit expectations gap and sought to establish its place in the commercial dynamics England. Demonstrated that a significant inconsistency of views existed on the bench and within the profession, causing a disjoint between the bench and the profession. Ebimobowei (2010) evaluated the issues and challenges of audit expectation gap, adopted the normative descriptive approach in the analysis of data found that the audit expectation gap is a very fundamental issue in every society in the world and that perception of users of financial statements as the responsibilities of auditors and the audit objective is the major cause of the gap. Therefore, better communication between the auditors and the society may help reduce the gap, which depends on the design and implementation of appropriate models by the profession to eliminate the gap completely.

Lee, Ali, and Gloeck (2009) investigated the causes of the audit expectation gap in Malaysia. 35 semi-structured in-depth interviews were conducted. This study found that the causes of the audit expectation gap in Malaysia are complicated. They arise from a combination of misconceptions or ignorance on the part of users, the complicated nature of the audit function, unreasonable expectations, inappropriate legislation, and underperformance by auditors due to reasons including "low balling" and unreasonable audit fees amongst others.Azham, Ali, Teck Heang, Mohamad, and Ojo (2008) Investigated whether internship program could reduce the audit expectation gap in Malaysia. Using a pre-post method, the research instrument adapted from Ferguson et al. (2000) which wasusedby UUM's accounting students before and after completing an internship program. The results showed a significant change in their perceptions after the internship program. However, changes in perceptions may not warrant an internship program as a means of reducing the audit expectation gap as misperceptions about the duties of auditors for fraud prevention and detection are still found among respondents. Nevertheless, an internship can still be used to complement audit education as it is an ideal way to expose students to professional issues and enables them to have a better insight of the actual performance and duties of auditors. Hodge, Subramaniam, and Stewart (2009) examined whether assurance, the level of assurance (reasonable vs limited) and the type of assurance practitioner (accountant vs specialist consultant) affect users' perceptions of reliability of sustainability reports. Based on an experimental questionnaire, they found that the provision of assurance improves perceived reliability of the environmental and social information. There were no significant main effects for both the level of assurance and type of assurance practitioner. However, a significant interaction was found between these two experimental factors and report users' perceptions of reliability of such reports. More specifically, report users place more confidence in sustainability reports when the level of assurance provided is reasonable (that is, high but not absolute), and when such assurance is provided by a top tier 
accountancy firm, compared to when the assurance is provided by a specialist consultant.

Porter, hÓgartaigh, and Baskerville (2009) conducted a research to ascertain the structure, composition and extent of the audit expectation-performance gap in the United Kingdom (UK) and New Zealand (NZ) in 2008. Identified and explained differences in the structure, composition and extent of the audit expectation-performance gap; ascertain society's (and, more particularly, financial statement users') understanding of the message(s) conveyed in a standard unqualified auditor's report; and identify changes to the format and wording of auditors' reports desired by society (and, more particularly, financial statement users). findings of the research werein spite of the fact that the structure and composition of the audit expectation-performance gap in the UK and NZ in 2008 were similar, the gap was significantly wider in NZ than in the UK. This finding differs markedly from that in 1999 when the extent of the gap in the two countries was found to be essentially the same. Between 1999 and 2008 the gap in the UK narrowed substantially while that in NZ widened slightly. The research findings suggests that the difference in the change in the gap in the UK and NZ may result from differences in the monitoring of auditors' performance in the twocountries and/or from greater publicity given to corporate, and financial reporting issues with audit implications in the UK. Moreover, notwithstanding the use of the long form audit report as an educational tool, financial statement users' (and other interest groups') misunderstanding of the audit function and auditors' responsibilities persists. This is supported by a further finding of the research, namely, that the content of a standard auditor's report has little impact on financial statement users' understanding of the messages conveyed in the report.

According to UKEssays (2015) the reasons an auditor may fail to recognize red flags auditing process includes: Over reliance on client representations, Lack of awareness or recognition of an observable condition indicating fraud, Lack of experience;Personal relationships with clients and Failure to brainstorm potential fraud schemes and scenarios, andA desire "not to know".

Furthermore, there are two main factors that may effect on the audit expectation gap:

1. The auditor's ability to detect fraud.

2. The auditor's efforts to detect fraud.

An auditor may possess the skills to detect fraud, but might choose to take shortcuts or disregard obvious signs of potential fraud. Or, an auditor might use a variety of techniques, but lack the experience to effectively uncover red flags (UKEssays, 2015). Moreover, an auditor must develop the requisite skills to detect fraud and obtain sufficient knowledge of the rules and regulations in order to better understand what is required during an audit. Statement on Auditing Standards (SAS) 99, Consideration of Fraud in a Financial Statement Audit, requires auditors to obtain "reasonable" assurance that material fraud is not present. 


\section{Conclusion}

Based on reviewing literatures and highlighting on theoretical framework, this paper concludes the following aspects that assist in bridging the gap between stakeholders and external auditors as follows:

1. Educating society about the audit function/nature, and what auditors can reasonably expect to accomplish is afforded when an infamous fraud and/or unexpectedcorporate failure reaches the media headlines.

2. Detecting Fraud from external auditors requires effort and the ability to work hand in hand. Ability is enhanced through experience, training, and effort. Effort is enhanced through solid audit plans, brainstorming and ability.

3. The challenge to bridge the expectation gap stands before auditors, while the profession has made great steps through legislation, regulation, and audit standards, it must apply this guidance within its own ranks, expending the effort and developing the ability to reduce this gap.

4. Better communication between the auditors and the society may help reduce the gap.

5. Developing auditors' skills assist in detecting fraud and obtaining sufficient knowledge of the rules and regulations in order to better understand what is required during an audit.

6. Clarifying for users should be done, that auditor's opinions don't mean a guarantee of accuracy of the financial statements.

\section{Recommendations}

After the overview on the audit expectation performance gap, and highlighted on some literatures that have dealt with audit gap, societies' perceptions. This study comes up with some of recommendations that might help in narrowing the audit gap such as:

- Increase the awareness of public about the auditors' responsibilities and duties, and increase the practitioners' (external auditors) skills and abilities through education and training.

- Increase the quality of audit standards, and continuous monitoring of auditors' performance.

\section{References}

Accountingtools. (2014). Users of financial statements from https://www.accountingtools.com/articles/users-of-financial-statements.html

Azham, Ali, M., Teck Heang, L., Mohamad, R., \& Ojo, M. (2008). Internship and audit expectation gap among undergraduate students in Universiti Utara Malaysia. Journal of Financial Reporting and Accounting, 6(1), 55-74.

Benedetto, F., \& Castri, S. D. (2005). There is Something about Parmalat. Retrieved 25.06, 2016, from http://papers.ssrn.com/sol3/papers.cfm?abstract_id=896940

Dixon, R., Woodhead, A., \& Sohliman, M. (2006). An investigation of the expectation gap in Egypt. Managerial Auditing Journal, 21(3), 293-302. 
Ebimobowei, A. (2010). An evaluation of audit expectation Gap: Issues and challenges. International Journal of Economic Development Research and Investment, 1, 129-141.

Handley-Schashler, M., \& Li, S. (2005). International Effects of The Andersen Accounting and Accounting Scandals: Some Evidence from the US, UK and Australian Stock Markets. Queenzland: Queensland university of technology.

Haniffa, R., \& Hudaib, M. (2007). Locating audit expectations gap within a cultural context: The case of Saudi Arabia. Journal of International Accounting, Auditing and Taxation, 16(2), 179-206.

Healy, P. M., \& Palepu, K. G. (2003). The fall of Enron. Journal of Economic Perspectives, 17(2), 3-26.

Hmoud, T. A., \& Mansour, H. (2012). The expectation gap between external auditors and credit officers in Jordanian commercial Jordanian banks. The Arab Journal of Accounting, $8(3), 15-25$.

Hodge, K., Subramaniam, N., \& Stewart, J. (2009). Assurance of sustainability reports: Impact on report users' confidence and perceptions of information credibility. Australian Accounting Review, 19(3), 178-194.

IFAC. (2012). A defifnition of public interests https://www.ifac.org/system/files/publications/files/PPP\%205\%20\%282\%29.pdf

Lee, T., Ali, A. M., \& Gloeck, J. D. (2009). The audit expectation gap in Malaysia: an investigation into its causes and remedies. Southern African Journal of Accountability and Auditing Research, 9(1), 57-88.

Lee, T. H., Gloeck, J. D., \& Palaniappan, A. (2007). The audit expectation gap: an empirical study in Malaysia. Southern African Journal of Accountability and Auditing Research, 7(1), 1-15.

Lexicon, F. (2017). lexicon.ft.com/Term?term=audit-expectation-gap

Masa'deh, R., Tayeh, M., Al-Jarrah, I., \& Tarhini, A. (2015). Accounting vs. market-based measures of firm performance related to information technology investments. International Review of Social Sciences and Humanities, 9(1), 129-145.

Masoud, N. (2017). An Empirical Study of Audit Expectation-Performance Gap: The Case of Libya. Research in International Business and Finance, 41, 1-15. doi: http://www.sciencedirect.com/science/journal/02755319

Munir Sidani, Y. (2007). The audit expectation gap: evidence from Lebanon. Managerial Auditing Journal, 22(3), 288-302. 
Obeidat, B., El-Rimawi, S., Maqableh, M., \& Al-Jarrah, I. (2013). Evaluating the profitability of the islamic banks in Jordan. European Journal of Economics, Finance and Administrative Sciences, 56, 27-36.

Obeidat, B., Tarhini, A., \& Aqqad, N. (2017). The impact of intellectual capital on innovation via the mediating role of knowledge management: a structural equation modelling approach. International Journal of Knowledge Management Studies, 8(3-4), 273-298.

Ojo, M. (2006). Eliminating the audit expectations gap: Reality or myth?

Okafor, C. A., \& Otalor, J. I. (2013). Narrowing the expectation gap in auditing: The role of the auditing profession. Research Journal of Finance and Accounting, 4(2), 43-52.

Oxford. (Ed.) (2010) Dictionary of accounting. Oxford University Press.

Porter, B., \& Gowthorpe, C. (2004). Audit expectation-performance gap in the United Kingdom in 1999 and comparison with the Gap in New Zealand in 1989 and in 1999: Citeseer.

Porter, B., hÓgartaigh, C. Ó., \& Baskerville, R. (2009). Report on research conducted in the United Kingdom and New Zealand in 2008 investigating the audit expectationperformance gap and users' understanding of, and desired improvements to, the auditor's report.

Pourheydari, O., \& Abousaiedi, M. (2011). An empirical investigation of the audit expectations gap in Iran. Journal of Islamic Accounting and Business Research, 2(1), 6376.

Rehana, F. (2010). An Empirical Study on Audit Expectation Gap: Role of Auditing Education in Bangladesh.

Salehi, M., \& Rostami, V. (2009). Audit expectation gap: International evidences. International Journal of Academic Research, 1(1).

Sylph, J. (2009). Bridging the expectation gap: Changing dimensions of an accountant's role. Paper presented at the ICAI Diamond Jubilee Conference.

Teo, E.-J., \& Cobbin, P. E. (2005). A revisitation of the "audit expectations gap": Judicial and practitioner views on the role of the auditor in late-Victorian England. Accounting History, 10(2), 35-66.

UKEssays. (2015). The audit expectation gap from https://www.ukessays.com/essays/business/the-audit-expectation-gap.php?cref=1 
Wedgandt, J. J., Kimmel, P. D., \& Kieso, D. E. (2015). Financial Accounting: IFRS Editon 3e: New York: John Wiley and Sons, Inc.

Zarrabi, S., \& Lunndberg, L. (2011). The Madoff Fraud. https://scholar.google.hu/scholar?hl=en\&as_sdt=0\%2C5\&q=Zarrabi\%2C+S.\%2C+\%26+Lu nndberg\%2C+L.+\%282011\%29.+The+Madoff+Fraud.+++.+\&btnG= 